\title{
Infrared Flow Cell for Use at Elevated Temperatures and Pressures
}

\author{
E. Oltay, J. M. L. Penninger, N. Alemdaroğlu, and J. M. Alberigs \\ Department of Chemical Engineering, Twente University of Technology, P.O. Box 217, Enschede, The Netherlands
}

Several types of cells have been used for in situ studies of chemical reactions at elevated temperature and pressure. Nearly all the cells can be characterized as small autoclaves equipped with windows, that is to say the cell itself acts as the reactor in which the reaction is carried out.

The cells described by Noack (1) and Tinker et al. (2) are made for the study of reactions carried out in a separate reactor. Only Noack's cell is of the flow type which enables continuous recording of absorbance at specific frequencies.

The limits of operation of the cells depend on the material used for the windows. The highest levels of temperature and pressure were reached with quartz and sapphire windows, e.g., with the $10 \mathrm{kbar}$ cell of Ewald et al. (3), the $280{ }^{\circ} \mathrm{C} 2.8 \mathrm{kbar}$ cell of Peters et al. (4), and the balanced pressure cell of Gruen (5) for $500^{\circ} \mathrm{C}$ and $2.1 \mathrm{kbar}$. The spectral application range of these cells, however, was limited to the near infrared region. On the other hand the regular infrared region was reached with conventional window materials such as sodium chloride and potassium bromide.

Since these materials are quite weak, the temperature and pressure range was limited to $100{ }^{\circ} \mathrm{C}$ and 200 bar for the flow cell of Noack (1), $100^{\circ} \mathrm{C}$ and 150 bar for the cell of Décsy et al. (6), and $200^{\circ} \mathrm{C}$ and 100 bar for the cell of Tinker (2).

An extension of this range was obtained with calcium fluoride as window material by Rigby et al. who claimed $200{ }^{\circ} \mathrm{C}$ at 1000 bar (7), but the spectral range of calcium fluoride is narrower than the range of both sodium chloride and potassium bromide.

The cell developed by us and described here is of the flow type and is primarily designed for chemical engineering purposes, e.g., in situ infrared recording of chemical reactions in gas-liquid systems, mixing characteristics of reactors under actual reaction conditions, sensor device of an automatic reactor control system etc.

A cross section of the cell is given in Figure 1 . The cell is made completely from stainless steel AISI 316 and has the following external dimensions: length $45 \mathrm{~mm}$, diameter $60 \mathrm{~mm}$. It is heated electrically by means of Thermocoax nichrome resistance wires of $1-\mathrm{mm} \mathrm{o.d}$. and thermally isolated in an asbestos box.

The temperature of the cell is measured with a calibrated Thermocoax chromel-alumel thermocouple of $1-\mathrm{mm}$ o.d. where the hot junction is fixed closely to the sample space.

The optical windows are $6 \mathrm{~mm}$ in length and $10 \mathrm{~mm}$ in diameter. They are forced by the internal pressure against packing rings of $0.1-\mathrm{mm}$ thickness which are seated on the

(1) K. Noack, Spectrochim. Acta, 24A, 1917 (1968).

(2) H. B. Tinker and D. E. Morris, Rev. Sci. Instrum, 43, 1024 (1972)

(3) A. H. Ewald and E. S. Merritt, Rev. Sci. Instrum., 36, 864 (1965).

(4) E. Peters and J. J. Byerley, Rev. Sci. Instrum. 34, 819 (1963).

(5) D. M. Gruen, D. S. Newman, and R. L. McBeth, Rev. Sci. Instrum., 39, 197 (1968).

(6) Z. Décsy, K. Bélafi, and B. Heil, Proc. Conf. Appl. Phys. Chem. 2nd, 1, 17 (1972)

(7) W. Rigby, R. Whyman, and K. Wilding, J. Phys. E. Sci. Instrum., 3, $1572(1970)$ window support plugs. The seal between windows and cell body consists of four Frenzelite-Multi (phenol formalde'hyde resin reinforced with asbestos) packing rings of 0.5 $\mathrm{mm}$ thickness alternated with four soft rings of the same thickness. These fit tightly in the cell body and around the windows and are compressed on one window by a window support plug and on the other by the packing compression screw.

This seal system provides a stress distribution which is divided equally around the cylindrical surface of the windows and has proved to be very reliable in long-run tests even with comparatively weak windows such as sodium chloride. The cell is placed directly in the light beam of the infrared spectrometer (Perkin-Elmer 337); the radiation enters and leaves the cell through the conical holes of the window support plugs. The angle of the cones, $6^{\circ} 2^{\prime}$, is equal to the angle of the converging beam; the aperture of the cell is $4 \mathrm{~mm}$.

Maximum operating conditions of the cell were highly dependent on the materials used for the soft packing as found by extensive tests carried out as follows. After insertion of the packing rings to be investigated, the cell was completely filled with hexane which was compressed by a hand pump. After the required temperature was attained, the hexane pressure in the cell was recorded for three days. Since the total volume of the cell and appendages was $5 \mathrm{~cm}^{3}$, only a minor leakage was necessary to cause a considerable pressure drop, e.g., a leakage of $0.03 \mathrm{~cm}^{3}$ caused a pressure drop of 100 bar as calculated from hexane compressibility.

The test results of limits of application of several packing materials are listed in Table I. Materials that are slightly compressible at ambient temperature, e.g., polytetrafluorethylene and its modifications proved to be the best.

The temperature rather than the pressure, was the most critical parameter for packing performance. With all materials investigated, leakage occurred suddenly in a range of approximately $10^{\circ} \mathrm{C}$ at the maximum temperature level. Lowering the temperature always resulted in leakage; however, after slightly increasing the packing compression once, a leak-free seal was again obtained.

The best of all materials investigated appeared to be Rulon. A long-run test with this packing material and sodium chloride as windows was continued for three weeks. Only at temperatures from 350 to $370{ }^{\circ} \mathrm{C}$ and pressures from 500 to 600 bar were pressure drops of 100 bar a day registered.

After the test, the sodium chloride windows appeared to have flowed plastically into the conical holes of the window support plugs over a distance of one to two $\mathrm{mm}$. For long term operation at these temperatures, windows with better mechanical properties, such as calcium fluoride, coated silicon, or Irtran- 6 have to be considered; however, the spectral range of application may then become limited.

The sample path length of the cell which can be set between zero and two millimeters by the position of one of the window support plugs, is determined via Beer's law by 
Table I. Maximum Limits of Operation Reached with Several Packing Materials

\begin{tabular}{|c|c|c|c|}
\hline \multirow[b]{2}{*}{ Packing material } & \multicolumn{2}{|c|}{$\begin{array}{l}\text { Test con- } \\
\text { ditions }\end{array}$} & \multirow[b]{2}{*}{ Results } \\
\hline & $\begin{array}{l}\text { Tem- } \\
\text { perature, } \\
{ }^{\circ} \mathrm{C}\end{array}$ & $\begin{array}{l}\text { Pres- } \\
\text { sure, } \\
\text { bar }\end{array}$ & \\
\hline \multirow{2}{*}{$\begin{array}{l}\text { Polytetrafluorethylene } \\
\text { (PTFE) }\end{array}$} & 190 & 400 & no pressure drop \\
\hline & 200 & 300 & severe leakage \\
\hline \multirow{2}{*}{$\begin{array}{l}\text { PTFE reinforced with } \\
25 \% \text { glass fiber }\end{array}$} & 200 & 400 & no pressure drop \\
\hline & $\left.\begin{array}{r}\text { above } \\
200\end{array}\right\}$ & 400 & severe leakage \\
\hline \multicolumn{4}{|l|}{ PTFE reinforced with } \\
\hline $25 \%$ molybdenum & 220 & 500 & no pressure drop \\
\hline sulfide & 270 & 500 & $\begin{array}{l}\text { pressure drop of } 100 \text { bar / } \\
\text { day }\end{array}$ \\
\hline \multirow[t]{2}{*}{ Fluorosint ${ }^{a}$} & 280 & 500 & no pressure drop \\
\hline & 190 & 300 & $\begin{array}{l}\text { leak free when pressurized } \\
\text { with hydrogen }\end{array}$ \\
\hline Kapton- $\mathrm{H}^{b}$ & 300 & 500 & $\begin{array}{c}\text { no pressure drop, packing } \\
\text { was brittle after test and } \\
\text { easily broke into pieces }\end{array}$ \\
\hline Kapton-F $b$ & 340 & 500 & $\begin{array}{c}\text { no pressure drop, packing } \\
\text { appeared as one mass } \\
\text { after test, no brittleness }\end{array}$ \\
\hline \multirow[t]{2}{*}{ Rulon-25 } & 350 & 500 & no pressure drop \\
\hline & 370 & 500 & $\begin{array}{l}\text { pressure drop of } 100 \text { bar / } \\
\text { day }\end{array}$ \\
\hline \multicolumn{4}{|c|}{$\begin{array}{l}\text { a The Polymer Corporation, Reading, Pa., reinforced PTFE of unknown } \\
\text { omposition. }{ }^{b} \text { Du Pont de Nemours, Wilmington, Del.: Kapton-H; poly- } \\
\text { mide film; Kapton-F: polyimide film coated with PTFE. c Dixon Corpora- } \\
\text { ion, Bristol, R. I., reinforced PTFE of unknown composition. }\end{array}$} \\
\hline
\end{tabular}

absorbance measurements of the fluid inserted at characteristic frequencies; e.g., with $n$-hexane the $1380 \mathrm{~cm}^{-1}$ and $1135 \mathrm{~cm}^{-1}$ frequencies were used for the sample path length ranges of up to $100 \mu \mathrm{m}$ and $1000 \mu \mathrm{m}$, respectively.

The sample path length, which is set at ambient temperature, changes with increase of temperature because of the thermal expansion of the various cell components. Calculations showed that the thermal expansion of the windows was the overriding factor; in the case of sodium chloride, a temperature rise from ambient to $300{ }^{\circ} \mathrm{C}$ reduces the path length by $90 \mu \mathrm{m}$.

Inherent to our cell design is a critical sample path length below which the flowing fluid does not pass between the windows but around the windows. This short circuiting of the sample space results in a stagnant fluid film between the windows and is deleterious for kinetic measurements.

Since the gap between the windows and the cell body is approximately $50 \mu \mathrm{m}$, short-circuiting may be expected to occur at sample path lengths of this order of magnitude. Experimental evidence for this was obtained in the following way. In a flow of hexane passing through the cell. acetone was injected upstream. The variation of the acetone concentration with time in the cell was detected by continuous absorbance measurements at the characteristic wavenumber of $1700 \mathrm{~cm}^{-1}$. The area enclosed by the absorbance curve and the time axis is proportional to the amount of acetone passing through the sample space.

Measurements were repeated at various path lengths and hexane flow rates. At a path length larger than $90 \mu \mathrm{m}$ (Figure 2), all the liquid entering the cell passes through the sample space. Below that value, short-circuiting oc-

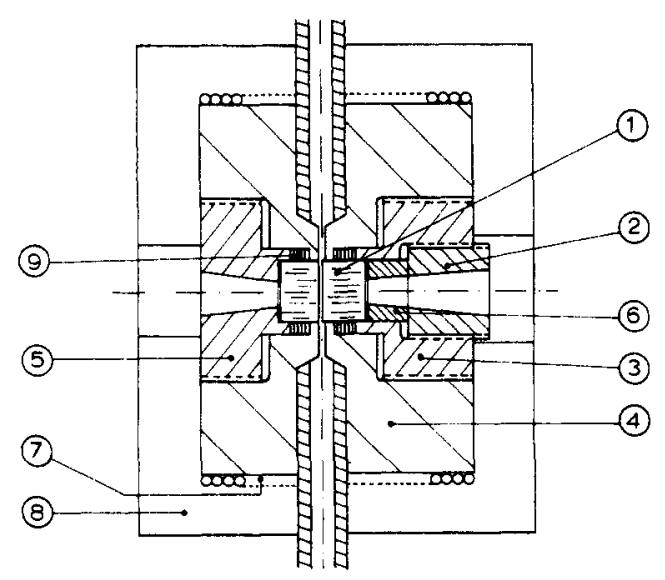

Figure 1. High temperature-pressure infrared flow cell

1. Windows: 2 . window support plug, also used for sample path length setting; 3 . packing compression screw; 4 . cell body; 5 . window support plug, also used for packing compression; 6 . spacer; 7 . heating element; 8. asbestos insulation box; 9 . packing rings

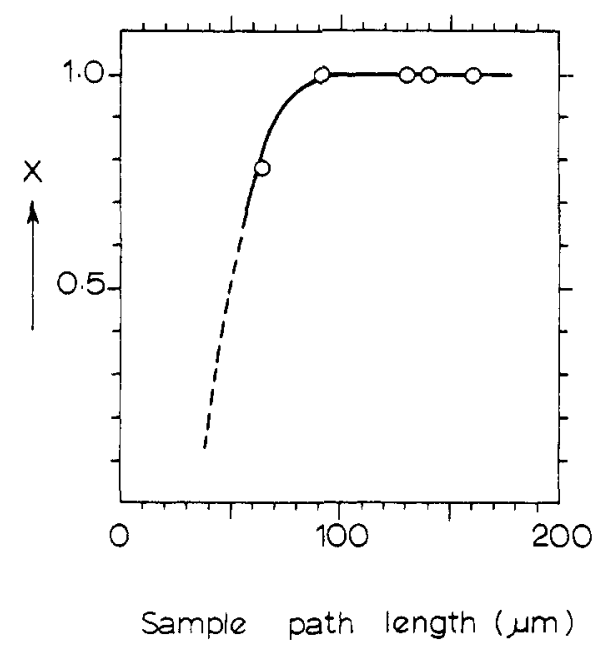

Figure 2. Volume fraction $X$ of fluid entering the cell and passing through sample space; flow rates of $n$-hexane ranging from 1.6 to $3.61 . / \mathrm{hr}$

curs. An approximate extrapolation of the curve in Figure 2 indicates a stagnant film region between zero and 30 to $40 \mu \mathrm{m}$. In practice this means that all sample path lengths larger than approximately $40 \mu \mathrm{m}$ are potentially suitable for continuous measurements.

The high temperature-pressure cell described above is in use for in situ kinetic studies of homogeneously catalyzed gas-liquid reactions which will be reported at a later date.

\section{ACKNOWLEDGMENT}

The authors are indebted to $\mathrm{H}$. Olde Veldhuis for his valuable contributions in design and construction of the cell, to Mrs. C. M. Meulstee-van Horn and R. Arends in preparation of the manuscript. Finally Mr. Ulbrich of Du Pont de Nemours, Germany, is acknowledged for kindly providing the Kapton films.

Received for review July 31, 1972. Accepted December 8, 1972. 